\title{
Erythropoiesis is Distinct at Each Stage of Ontogeny
}

\author{
RONA S. WEINBERG, LIYA HE, AND BLANCHE P. ALTER \\ Polly Annenberg Levee Hematology Center, Departments of Medicine and Pediatrics, Mount Sinai School of \\ Medicine, New York, New York 10029
}

\begin{abstract}
In vitro erythropoiesis from fetuses, newborn infants, and adults was compared in methyl cellulose cultures. Fetal and newborn blood erythroid colony formation tended to be more sensitive to erythropoietin than adult. The day of maximal colony formation was earlier in fetal than in newborn or adult cultures. The number of colonies/100 000 mononuclear cells on d 13 of culture and on the day of peak growth was highest in fetal, intermediate in newborn, and lowest in adult cultures. Burst forming units-erythroid/mL of blood on culture $\mathrm{d} 13$ and the day of peak growth were similar in fetuses and newborns, and both were significantly greater than in adults. The proportional synthesis of $\gamma$-globin in fetal colonies was 2 -fold greater than in newborn colonies, and 6-fold greater than in adult colonies. Thus, fetal, newborn, and adult erythroid progenitor cultures are each unique with regard to erythropoietin sensitivity, growth time course, number of erythroid colonies, and the proportion of $\gamma$-globin synthesis. (Pediatr Res 31: 170-175, 1992)
\end{abstract}

\section{Abbreviations}

BFU-E, burst forming unit-erythroid

CFU-E, colony forming unit-erythroid

Ep, recombinant human erythropoietin

Ep $1 / 2$ max, concentration of erythropoietin at which halfmaximal growth was achieved

Ep plateau, concentration of erythropoietin beyond which no additional growth was observed

MNC, mononuclear cells

In vitro semisolid culture assays have been used extensively to characterize erythroid progenitor cells and to study erythropoiesis during normal human ontogeny. Although not morphologically identifiable, erythroid progenitor cell classes can be identified by the phenotypes of the clonal colonies that they form in vitro. The earliest identifiable committed erythroid progenitor cell is the BFU-E, which further differentiates into the CFU-E, which in turn produces erythroblasts.

During intrauterine development, erythropoiesis occurs first in the embryonic yolk sac, then the fetal liver, and finally in the bone marrow, which becomes the definitive hematopoietic organ in the newborn and adult. Erythroid cell cultures have demonstrated the presence of erythroid progenitor cells at serial gestational ages in the yolk sac $(1,2)$, liver $(3-6)$, bone marrow $(3,7)$,

Received June 25, 1991; accepted September 12, 1991.

Correspondence and reprint requests: Rona S. Weinberg, Ph.D., Mount Sinai School of Medicine, Division of Hematology, Box 1079, One Gustave Levy Place, New York, NY 10029.

Supported in part by grants from the National Institutes of Health (HL26132, HL38655, and DK41938) and a scholarship from the American Foundation for AIDS Research (R.S.W.) and blood $(3,8,9)$ of fetuses, as well as in the bone marrow and blood of newborn infants $(3,6,10)$ and adults $(11,12)$.

We have previously demonstrated that colonies derived from newborn and adult blood BFU-E have different globin synthesis phenotypes $(13,14)$. The studies presented here were designed to further characterize fetal, newborn, and adult blood erythropoiesis with regard to Ep sensitivity, kinetics of colony growth, number of progenitor cells, and proportion of $\gamma$-globin synthesis. We present evidence that erythropoiesis is distinct at each stage of ontogeny.

\section{MATERIALS AND METHODS}

Blood studies. All procedures were approved by the Institutional Review Board of the Mount Sinai School of Medicine. Fetal blood was obtained at the time of elective termination of pregnancy from the umbilical veins of normal 18- to 23-wk gestational age fetuses. Newborn blood was obtained from the umbilical cords of term newborn infants immediately after delivery. Adult blood was from the antecubital vein of normal donors, 20-45 y of age. Blood samples were collected into syringes containing $50 \mathrm{U}$ heparin (Liquaemin; Organon Inc., West Orange, $\mathrm{NJ}$ )/mL blood or into heparinized Vacutainer blood collection tubes (Becton-Dickenson, Rutherford, NJ). To prepare MNC, blood was diluted 1:1 with alpha medium (GIBCO Laboratories, Grand Island, NY), layered onto an equal volume of Ficoll-Paque (Pharmacia Fine Chemicals, Piscataway, NJ), and centrifuged at $450 \times g$ for $30 \mathrm{~min}$ at $18^{\circ} \mathrm{C}(13,15)$.

Fetal liver studies. Fetal livers were obtained from normal 18 to 23-wk gestational age fetuses after elective termination of pregnancy. The livers were cut into small pieces with sterile scissors and then incubated in alpha medium containing $5 \mathrm{mg}$ collagenase (Sigma Chemical Co., St. Louis, MO) $/ \mathrm{mL}$ for 30 min at $37^{\circ} \mathrm{C}$. After incubation, liver cell suspensions were passed through a sterile fine-wire mesh, then vigorously pipetted, and finally passed through successively smaller bore syringe needles to prepare single-cell suspensions. Fetal liver MNC were prepared by layering fetal liver cell suspensions onto equal volumes of Ficoll-Paque, followed by centrifugation at $450 \times g$ for $30 \mathrm{~min}$ at $18^{\circ} \mathrm{C}$.

Erythroid cultures. MNC were cultured in $0.8 \%$ methyl cellulose according to methods previously described $(13,15)$. Each mL of culture contained: $2.5-5.0 \times 10^{4}$ fetal, $1 \times 10^{5}$ newborn, or $3 \times 10^{5}$ adult MNC, $0.8 \%$ methyl cellulose (Fisher Scientific Co., Pittsburgh, PA) in alpha medium without nucleosides (GIBCO L Laboratories), 30\% fetal bovine serum (Armour Pharmaceutic Intergen Company, Purchase, NY), 1\% BSA (Cohn faction IV; Sigma Chemical Co.), $10^{-4} \mathrm{M}$ 2-mercaptoethanol (Sigma Chemical Co.), $0.1 \mathrm{U}$ penicillin, and $0.1 \mu \mathrm{g}$ streptomycin/ $\mathrm{mL}$ (GIBCO Laboratories). Ep was kindly provided by Ortho Pharmaceutical Corporation (Raritan, NJ). All cultures (except for Ep dose-response studies) contained $2 \mathrm{U} \mathrm{Ep/mL}$ culture. Cultures were done in triplicate in $0.3-\mathrm{mL}$ volumes in NUNC four-well dishes (Intermed, Rosklide, Denmark) and incubated 
at $37^{\circ} \mathrm{C}$ in $4 \% \mathrm{CO}_{2}$. Colonies derived from CFU-E were counted on culture $\mathrm{d} 7$ (seen only in fetal liver cultures), and those derived from BFU-E were counted on d 9, 13, 17, and 20 after plating using a Bausch \& Lomb Stereozoom dissecting microscope (Bausch \& Lomb, Rochester, NY). BFU-E/mL = BFU-E/ 100000 cells plated $\times$ number of $\mathrm{MNC} / \mathrm{mL}$ of blood.

Globin synthesis. Globin synthesis by colonies was examined by labeling with ${ }^{3} \mathrm{H}$-leucine, electrophoresis of culture lysates on polyacrylamide gels containing acetic acid, urea, and Triton X100 , and fluorography of gels, followed by densitometric analyses. BFU-E-derived colonies were labeled from culture d 9-10, 13-14, 16-17, and 20-21. Fetal $\mathrm{Hb}(\mathrm{Hb} \mathrm{F})$ is composed of two $\alpha$ - and two $\gamma$-globin chains. There are two $\gamma$-chains, ${ }^{\mathrm{G}} \gamma$ and ${ }^{\mathrm{A}} \gamma$, with glycine or alanine in amino acid position 136. Adult $\mathrm{Hb}$ ( $\mathrm{Hb} \mathrm{A}$ ) is composed of two $\alpha$ - and two $\beta$-chains. The percentage of $\gamma$-globin (or $\mathrm{Hb} \mathrm{F})=100 \times \gamma /(\gamma+\beta)$. The percentage of ${ }^{\mathrm{G}} \gamma$ globin $=100 \times{ }^{\mathrm{G}} \gamma /\left({ }^{\mathrm{G}} \gamma+{ }^{\mathrm{A}} \gamma\right)$. Detailed procedures have been reported elsewhere $(13,15)$. All data shown are the means of triplicate analyses.

\section{RESULTS}

Ep dose-response curves for fetal, newborn, and adult blood BFU-E-derived colonies on d 13 of culture are shown in Figure 1. No colonies were observed without the addition of erythropoietin. When average growth was compared at a low dose of Ep $(0.1 \mathrm{U} \mathrm{Ep} / \mathrm{mL})$, the highest proportion of total growth was observed in fetal blood cultures (31\% of maximal growth), newborn colony growth was intermediate $(23 \%)$, and adult colony growth was the lowest (13\%) (Table 1). The most significant observation was that some of the fetal and newborn cultures grew well at $<0.1 \mathrm{U} \mathrm{Ep} / \mathrm{mL}$, whereas none of the adult cultures did so. The Ep 1/2 max (Fig. 2 and Table 1) and the Ep plateau (Fig. 3 and Table 1) indicate the sensitivity of erythroid progenitor cells to Ep. The range of Ep $1 / 2$ max was lower for fetal cultures than for newborn or adult cultures. All fetal cultures reached half-maximal growth with doses of $\mathrm{Ep} \leq 0.52 \mathrm{U} / \mathrm{mL}$, whereas one newborn and two adult cultures required higher doses of Ep to achieve half-maximal growth. The Ep plateau was $\leq 2 \mathrm{U} / \mathrm{mL}$ in four of five fetal cultures and seven of seven newborn cultures. In contrast, only four of nine adult cultures reached plateau growth with doses $\leq 2 \mathrm{Ep} / \mathrm{mL}$, and the remaining five cultures required $4 \mathrm{U} \mathrm{Ep} / \mathrm{mL}$ for colony growth to plateau.

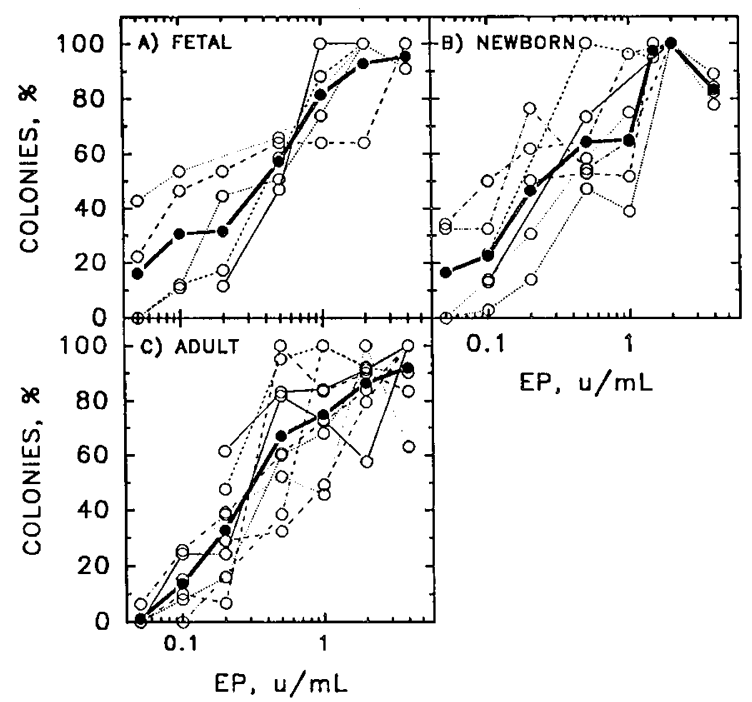

Fig. 1. Erythropoietin dose-response curves of blood BFU-E-derived colonies from fetuses, newborn infants, and adults. Data were normalized as the percentage of maximal growth. Each curve with open symbols represents a different donor, and each point is the mean of triplicate cultures. The curve with solid symbols represents the mean of all curves. Fetal $(A)$, newborn $(B)$, and adult $(C)$ blood.
Thus, fetal and newborn BFU-E tended to be more sensitive to Ep than adult BFU-E, requiring lower doses to achieve maximal growth.

Figures 4 and 5 demonstrate the growth time course of blood BFU-E-derived colonies, and the data are summarized in Table 1 . In two of 13 fetal cultures, maximal growth occurred by $\mathrm{d} 10$ of culture. In five more, peak growth was by $\mathrm{d} 13$. Four more peaked by $\mathrm{d} 16$, and only two more by d 20 . Peak growth of newborn colonies was slightly later, with no peak growth before d 13, at which time only three of 13 achieved maximal growth; eight more reached peak growth by $\mathrm{d} 16$, and two more, by $\mathrm{d}$ 20 . Growth of normal adult colonies peaked at the same time as newborn colonies. In adult cultures, the earliest peak growth was by culture $d 13$ in only eight of 20 cultures; seven more peaked by $\mathrm{d} 16$, and the remaining five, by $\mathrm{d} 20$.

Figure 6 compares blood BFU-E-derived colony growth on $d$ 13 and on the peak day, which is often later than $\mathrm{d} 13$ as shown above. In panels $A$ and $B$, the data are expressed as colonies/ $100000 \mathrm{MNC}$ plated. On both $\mathrm{d} 13$ and the day of peak growth, fetal colonies were the most numerous, followed by newborn colonies, whereas adult colonies were the fewest in number. Because the number of $\mathrm{MNC} / \mathrm{mL}$ of blood obtained by FicollHypaque centrifugation is often higher from newborn than fetal or adult blood (mean $\times 10^{5}$ cells $/ \mathrm{mL}$ blood $\pm 1 \mathrm{SD}$ : fetal $=19$ \pm 11 , newborn $=40 \pm 25$, adult $=17 \pm 6$ ), data are expressed as BFU-E/mL blood in panels $C$ and $D$ to provide a more physiologic comparison. This comparison demonstrated that the concentration of fetal and newborn BFU-E were similar to each other and both were significantly higher than adult BFU-E on $d$ 13 and the peak day. The means, ranges, and $p$ values for these experiments are shown in Table 1.

Fetal liver erythroid progenitor cell growth is shown in Figures 5 and 7 . In contrast with fetal blood, fetal liver MNC contained both CFU-E and BFU-E. Fetal liver BFU-E-derived colonies were more numerous than fetal blood BFU-E-derived colonies on both culture $\mathrm{d} 13$ and the day of peak growth $(p=0.023$ and 0.017 , respectively). Fetal liver BFU-E-derived colonies peaked slightly later than fetal blood colonies (mean day of peak growth $=16.4$ versus 14.5 , respectively. No fetal liver cultures achieved peak growth by d 10, two of five peaked by d 13, one more peaked by $\mathrm{d} 16$, and maximal growth occurred by $\mathrm{d} 20$ in the remaining two cultures.

Figure 8 demonstrates the time course of globin synthesis. A temporal decline in $\gamma$-globin synthesis was observed at all stages of ontogeny. At all times, fetal was highest and newborn was next, followed by adult $\gamma$-globin synthesis. ${ }^{\mathrm{G}} \gamma$-globin did not decline with time and was highest in the fetal cultures. Figure 9 shows globin synthesis in individual cultures of fetal, newborn, and adult blood BFU-E-derived colonies on d 13. Means, ranges, and $p$ values are shown in Table 1 .

\section{DISCUSSION}

We have compared the growth characteristics of peripheral blood erythropoiesis from fetuses, newborn infants, and adults. For the parameters that were examined, each ontogenic stage has a unique "phenotype."

Ep sensitivity. The Ep sensitivities of fetal, newborn, and adult blood progenitor cells were compared by examining the proportion of colony growth at a low dose of $\mathrm{Ep}(0.1 \mathrm{U} \mathrm{Ep} / \mathrm{mL}), \mathrm{Ep} \mathrm{1/2}$ max, and Ep plateau. Fetal cultures had the highest proportion of growth with low $\mathrm{Ep}(31 \%)$ and the lowest $\mathrm{Ep} 1 / 2 \max (\leq 0.5 \mathrm{U}$ $\mathrm{Ep} / \mathrm{mL}$ ). Newborn cultures had intermediate growth at low Ep (23\%), and the Ep $1 / 2$ max was slightly higher than in fetal cultures and similar to that in adult cultures. The Ep plateau was similar in all cultures. The Ep sensitivities in our studies were similar to those previously reported for fetal $(8,9,16)$, newborn $(3,6,10$, $17)$, and adult $(9,17-19)$ blood progenitors. The apparent bimodality of the Ep dose-response curves in some fetal and newborn studies is consistent with the possibility that blood at 
Table 1. Characteristics of blood BFU-E-derived colonies

\begin{tabular}{|c|c|c|c|c|c|c|c|c|c|c|}
\hline & & \multirow[b]{2}{*}{ Fetal } & \multirow[b]{2}{*}{$n$} & \multirow[b]{2}{*}{ Newborn } & \multirow[b]{2}{*}{$n$} & \multirow[b]{2}{*}{ Adult } & \multirow[b]{2}{*}{$n$} & \multicolumn{3}{|c|}{$p$ values* } \\
\hline & & & & & & & & $\mathrm{F} v s \mathrm{~N}$ & $\mathrm{~N}$ vs $\mathrm{A}$ & $\mathrm{F} v s \mathrm{~A}$ \\
\hline $\begin{array}{l}\text { Colonies/100 } 000 \text { cells, } \\
\text { on d } 13\end{array}$ & $\begin{array}{l}\text { Meant } \\
\text { Range }\end{array}$ & $\begin{array}{c}141 \pm 109 \\
24-383\end{array}$ & 13 & $\begin{array}{r}59 \pm 22 \\
26-107\end{array}$ & 13 & $\begin{array}{c}17 \pm 11 \\
2-40\end{array}$ & 20 & 0.01 & $<0.001$ & $<0.001$ \\
\hline $\begin{array}{l}\text { Colonies } / 100000 \text { cells, } \\
\text { on peak day }\end{array}$ & $\begin{array}{l}\text { Mean } \\
\text { Range }\end{array}$ & $\begin{array}{c}190 \pm 120 \\
24-383\end{array}$ & 13 & $\begin{array}{r}95 \pm 42 \\
40-176\end{array}$ & 13 & $\begin{array}{c}21 \pm 11 \\
4-40\end{array}$ & 20 & 0.01 & $<0.001$ & $<0.001$ \\
\hline $\mathrm{BFU}-\mathrm{E} / \mathrm{mL}$, on d 13 & $\begin{array}{l}\text { Mean } \\
\text { Range }\end{array}$ & $\begin{array}{c}2886 \pm 2921 \\
323-8966\end{array}$ & 13 & $\begin{array}{c}2256 \pm 1509 \\
575-5959\end{array}$ & 13 & $\begin{array}{c}277 \pm 204 \\
27-758\end{array}$ & 20 & 0.49 & $<0.001$ & $<0.001$ \\
\hline $\begin{array}{l}\text { BFU-E/mL, on peak } \\
\text { day }\end{array}$ & $\begin{array}{l}\text { Mean } \\
\text { Range }\end{array}$ & $\begin{array}{r}4299 \pm 3878 \\
323-11730\end{array}$ & 13 & $\begin{array}{c}3517 \pm 2302 \\
732-9535\end{array}$ & 13 & $\begin{array}{r}365 \pm 225 \\
45-1007\end{array}$ & 20 & 0.54 & $<0.001$ & $<0.001$ \\
\hline Day of peak growth & $\begin{array}{l}\text { Mean } \\
\text { Range }\end{array}$ & $\begin{array}{c}14.5 \pm 3.2 \\
10-20\end{array}$ & 13 & $\begin{array}{c}15.9 \pm 2.2 \\
13-20\end{array}$ & 13 & $\begin{array}{c}15.5 \pm 2.8 \\
13-20\end{array}$ & 20 & 0.21 & 0.60 & 0.38 \\
\hline $\begin{array}{l}0.1 \mathrm{U} \mathrm{Ep} / \mathrm{mL}, \% \text { maxi- } \\
\text { mal growth }\end{array}$ & $\begin{array}{l}\text { Mean } \\
\text { Range }\end{array}$ & $\begin{array}{c}31 \pm 23 \\
11-54\end{array}$ & 4 & $\begin{array}{c}23 \pm 17 \\
3-50\end{array}$ & 6 & $\begin{array}{r}13 \pm 9 \\
0-26\end{array}$ & 9 & 0.5 & 0.1 & 0.05 \\
\hline $\operatorname{Ep} 1 / 2 \operatorname{maximal}(\mathrm{U} / \mathrm{mL})$ & $\begin{array}{l}\text { Mean } \\
\text { Range }\end{array}$ & $\begin{array}{l}0.3 \pm 0.2 \\
0.1-0.5\end{array}$ & 5 & $\begin{array}{c}0.4 \pm 0.3 \\
0.1-1.1\end{array}$ & 7 & $\begin{array}{l}0.4 \pm 0.3 \\
0.1-1.0\end{array}$ & 9 & 0.77 & 0.84 & 0.56 \\
\hline Ep plateau $(U / m L)$ & $\begin{array}{l}\text { Mean } \\
\text { Range }\end{array}$ & $\begin{array}{c}2.2 \pm 1.1 \\
1.0-4.0\end{array}$ & 5 & $\begin{array}{l}1.7 \pm 0.6 \\
0.5-2\end{array}$ & 7 & $\begin{array}{l}2.7 \pm 1.6 \\
0.5-4.0\end{array}$ & 9 & 0.33 & 0.13 & 0.52 \\
\hline$\% \gamma$-globin on $\mathrm{d} 13$ & $\begin{array}{l}\text { Mean } \\
\text { Range }\end{array}$ & $\begin{array}{r}82 \pm 5 \\
70-88\end{array}$ & 11 & $\begin{array}{c}44 \pm 12 \\
30-70\end{array}$ & 13 & $\begin{array}{r}13 \pm 9 \\
5-40\end{array}$ & 25 & $<0.01$ & $<0.01$ & $<0.01$ \\
\hline$\%^{\mathrm{G}} \gamma$-globin on $\mathrm{d} 13$ & $\begin{array}{l}\text { Mean } \\
\text { Range }\end{array}$ & $\begin{array}{r}66 \pm 6 \\
58-78 \\
\end{array}$ & 11 & $\begin{array}{r}55 \pm 7 \\
42-70 \\
\end{array}$ & 11 & $\begin{array}{c}53 \pm 14 \\
26-76\end{array}$ & 22 & $<0.01$ & 0.62 & $<0.01$ \\
\hline
\end{tabular}

* F, fetal; N, newborn; and A, adult.

$\dagger \pm 1 \mathrm{SD}$.

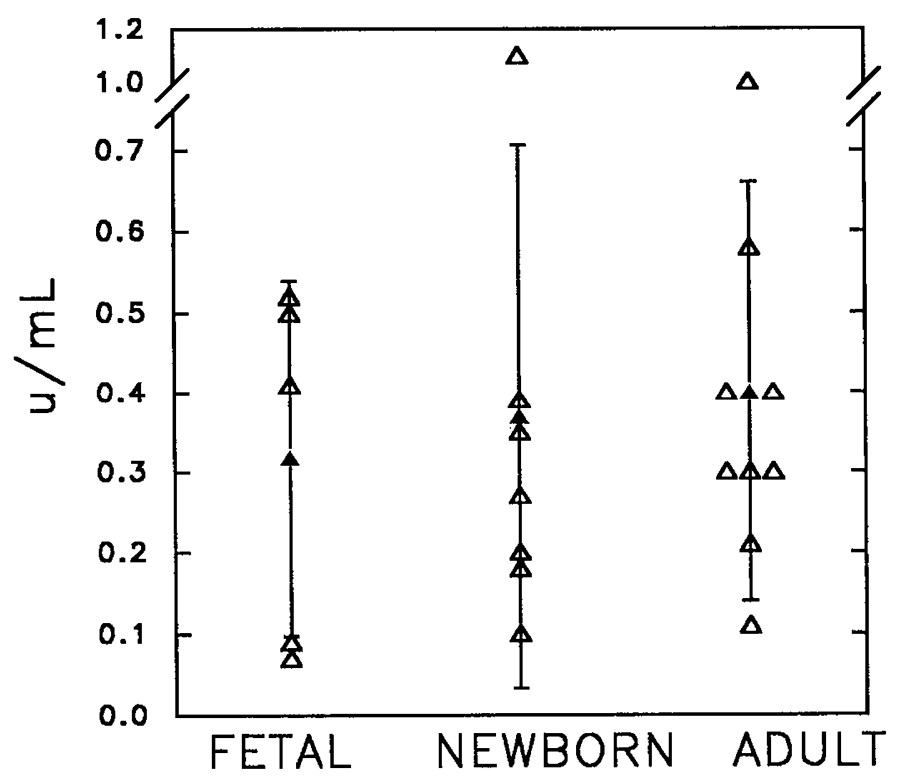

Fig. 2. Ep $1 / 2$ max for growth of blood BFU-E-derived colonies from fetuses, newborn infants, and adults. The Ep $1 / 2$ max was obtained from corresponding Ep dose-response curves. Open symbols represent individual experiments; solid symbols represent the mean $\pm 1 \mathrm{SD}$.

those stages contains fetal and adult progenitor cells (13); the fetal progenitors grew at Ep concentrations $\leq 0.1 \mathrm{U} / \mathrm{mL}$.

Time course. Many laboratories assay blood BFU-E at a single time point, $d 13$ or 14 of culture $(5,7,12)$. We examined cultures at 3- to 4-d intervals from d 9 to $d 20$, and we noted that less than half of all cultures reached their maximal growth potential by $\mathrm{d} 13$. We therefore present our data on $\mathrm{d} 13$ for comparison with other laboratories and also our data on the day of peak growth to demonstrate the maximum growth potential. The day of peak growth was earliest for fetal blood cultures and later for newborn and adult cultures, which were similar to each other.

Growth potential. The number of colonies/100 000 cells was greatest (2.5 times newborn and 10 times adult) in fetal, intermediate in newborn (three times adult), and lowest in adult cultures. Although the total number of each type of colony/

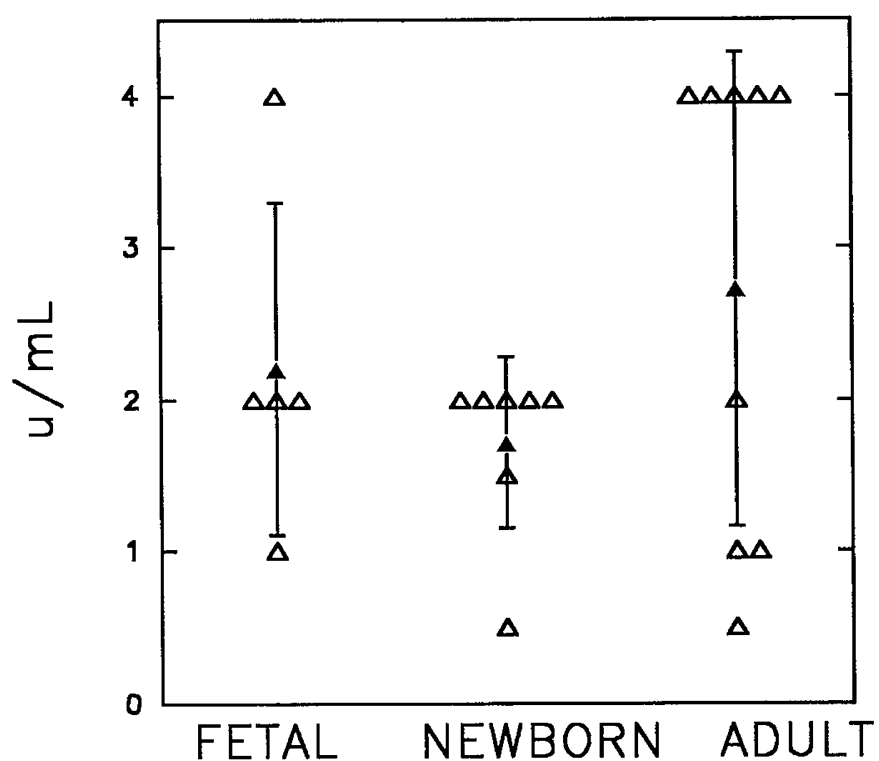

Fig. 3. Ep plateau for the growth of blood BFU-E-derived colonies from fetuses, newborn infants, and adults. Symbols are as in Figure 2.

100000 cells increased by the peak day, the relative frequency between groups remained similar. The number of colonies/ 100000 cells previously reported for fetal (7-9), newborn $(3,5$, $6,8,13,17,20-23)$, and adult $(5,6,8,12,18,20,24-27)$ blood cultures were $40-500,9-220$, and $2-256$, respectively. Our values fall within the ranges reported by others. However, careful inspection of the literature fails to adequately demonstrate the dramatic differences that actually exist between ontogenic classes of progenitor cells. These differences become more apparent when all ontogenic stages are compared in the same laboratory with the same techniques and reagents as in our studies. Our data are also presented as the number of BFU-E/mL in the circulation to provide a more physiologic comparison. Fetal and newborn BFU-E/mL were similar to each other, and both were significantly more numerous than adult BFU-E/mL on $\mathrm{d} 13$ and on the peak day $(>3000 / \mathrm{mL}$ vs approximately $300 / \mathrm{mL})$. The relatively high numbers of $\mathrm{BFU}-\mathrm{E} / \mathrm{mL}$ in fetuses and newborn 


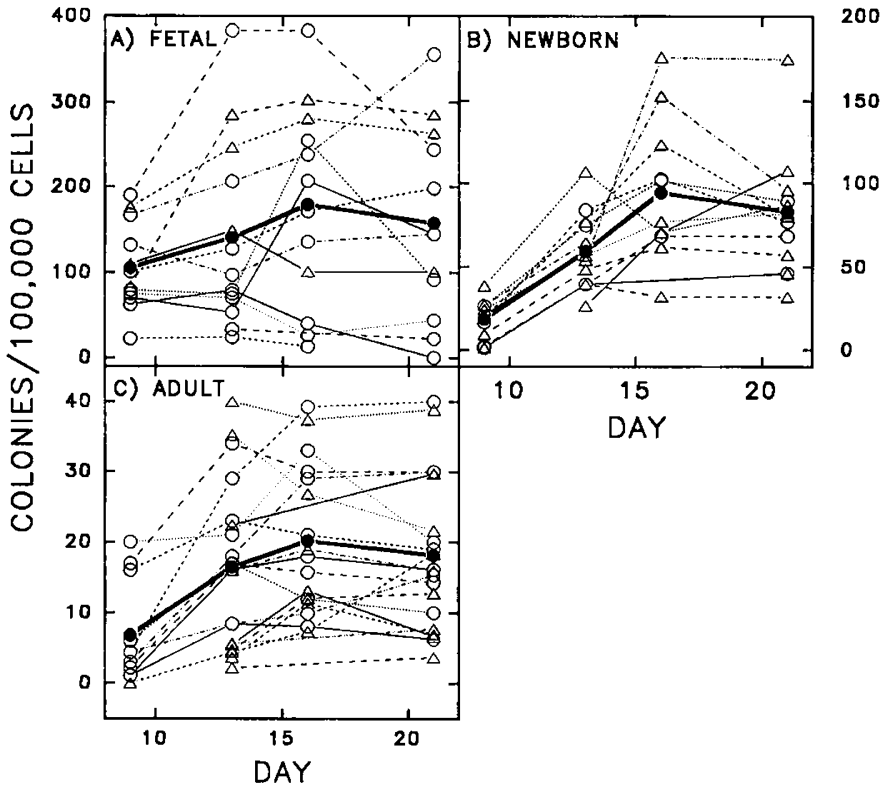

Fig. 4. Time courses of blood BFU-E-derived colony growth from fetuses, newborn infants, and adults, showing numbers of colonies/ $100000 \mathrm{MNC}$ plated. Data were normalized as the percentage of maximal growth. Each curve with open symbols represents a different donor, and each point is the mean of triplicate cultures. The curve with solid symbols represents the mean of all curves.

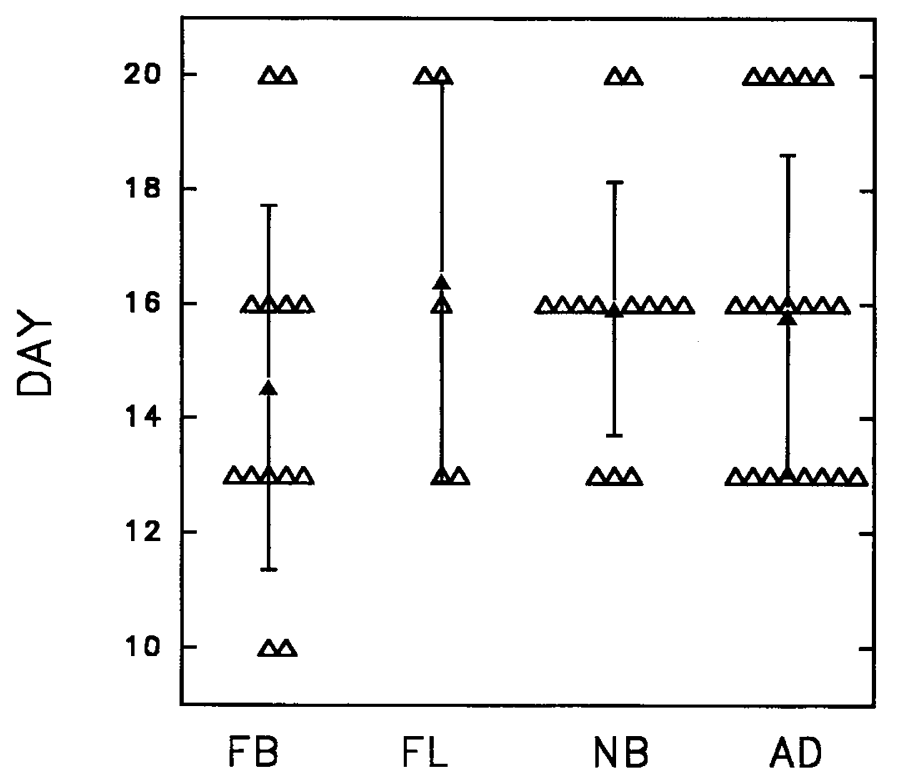

Fig. 5. Day of maximal BFU-E-derived colony growth from fetal liver $(F L)$ and blood from fetuses $(F B)$, newborn infants $(N B)$, and adults $(A D)$. Symbols are as in Figure 2.

infants may reflect the continuous expansion of the erythropoietic pool in rapidly growing fetuses and newborn infants. It may also be a compensatory response to the physiologic stresses associated with delivery. In contrast, normal adults are generally in an erythropoietic steady state.

Globin synthesis. Relative $\gamma$-globin synthesis on d 13 was 2 fold greater in fetal (82\%) than newborn cultures (44\%), and 3fold greater in newborn than adult cultures $(13 \%)$. In cultures from all three ontogenic classes of progenitors, a temporal decline in the proportion of $\gamma$-globin synthesis was observed, as reported previously $(8,28,29)$. The proportion of $\gamma$-globin that was ${ }^{G} \gamma$ also decreased with ontogenic stage.

In summary, erythropoiesis in cultures of fetal blood BFU-E are the most sensitive to Ep, and develop into colonies earliest.

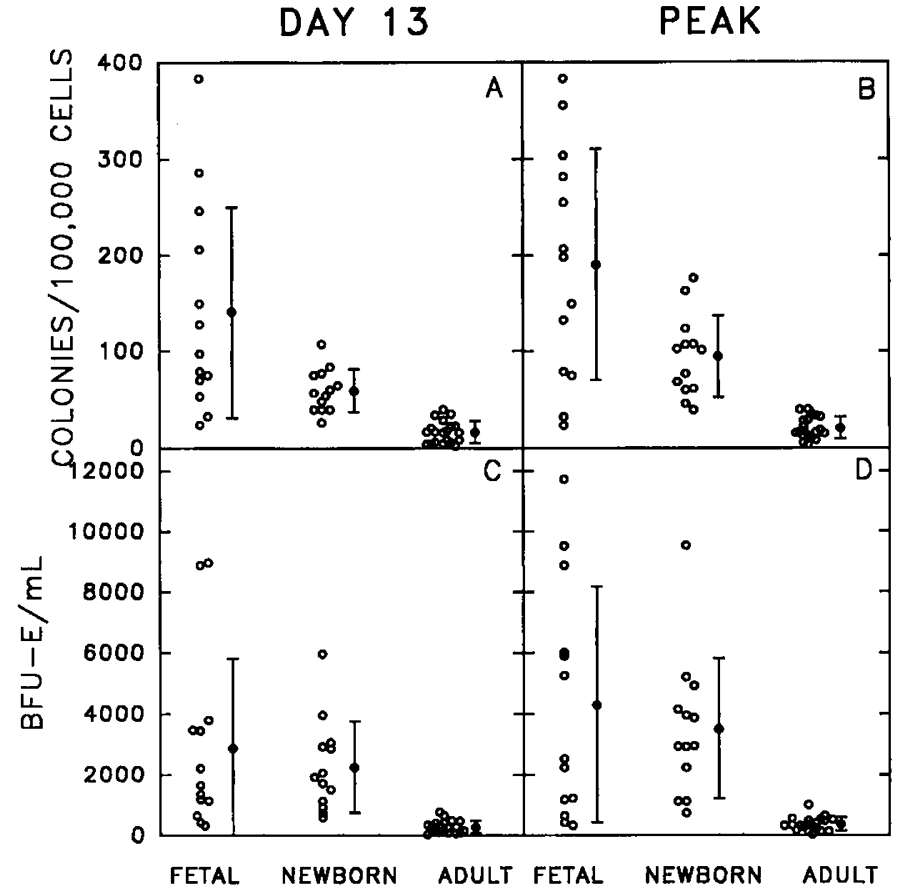

Fig. 6. Growth potential of blood erythroid progenitors from fetuses, newborn infants, and adults. $A$ and $C$ are data from d $13 ; B$ and $D$ are data from the day of peak growth. In $A$ and $B$, data are expressed as colonies/100 000 cells plated. In $C$ and $D$, data are expressed as BFU-E/ $\mathrm{mL}$ of blood. Symbols are as in Figure 2.

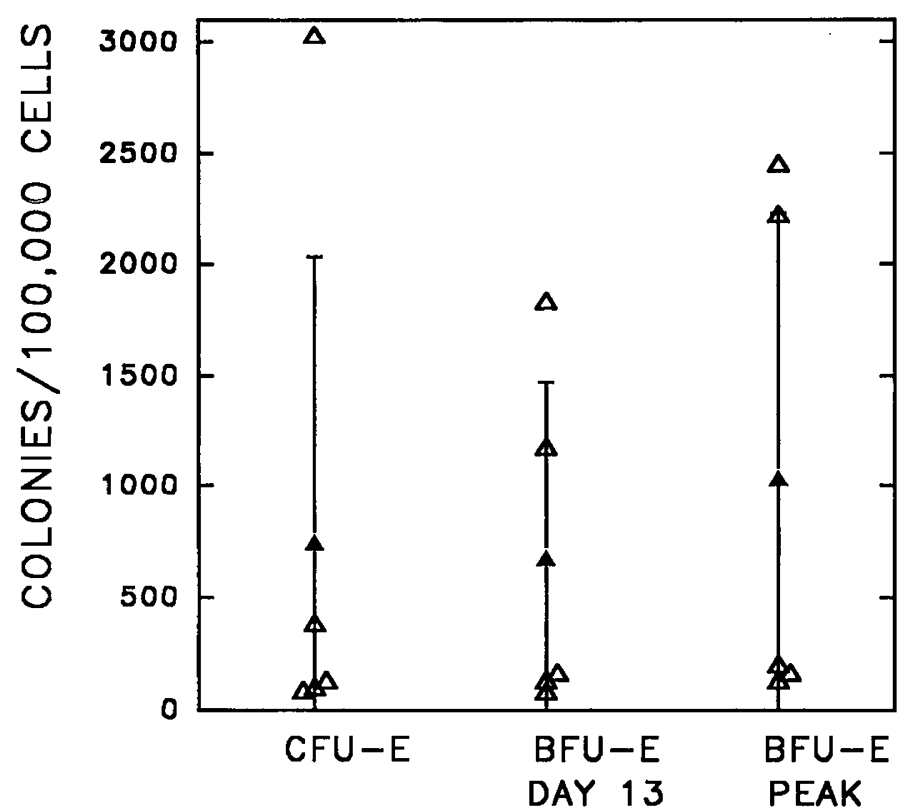

Fig. 7. Growth of colonies from cultures of fetal liver MNC. Symbols are as in Figure 2.

The fetal colonies are the most numerous and synthesize the highest proportion of $\gamma$-globin. Cultures from newborn infants are less sensitive to $\mathrm{Ep}$, contain an intermediate quantity of colonies, and their colonies synthesize an intermediate proportion of $\gamma$-globin. Adult cultures exhibit Ep sensitivity that is similar to newborn cultures; their colonies are fewest in number and synthesize the lowest proportion of $\gamma$-globin. We conclude that erythropoiesis is unique at each stage of ontogeny.

Our cultures used total MNC, in media-containing sera. We thus cannot discriminate between ontogenic uniqueness of BFU$\mathrm{E}$ per se and differences in accessory cells (monocytes and lymphocytes) in the MNC fraction. The composition of the 


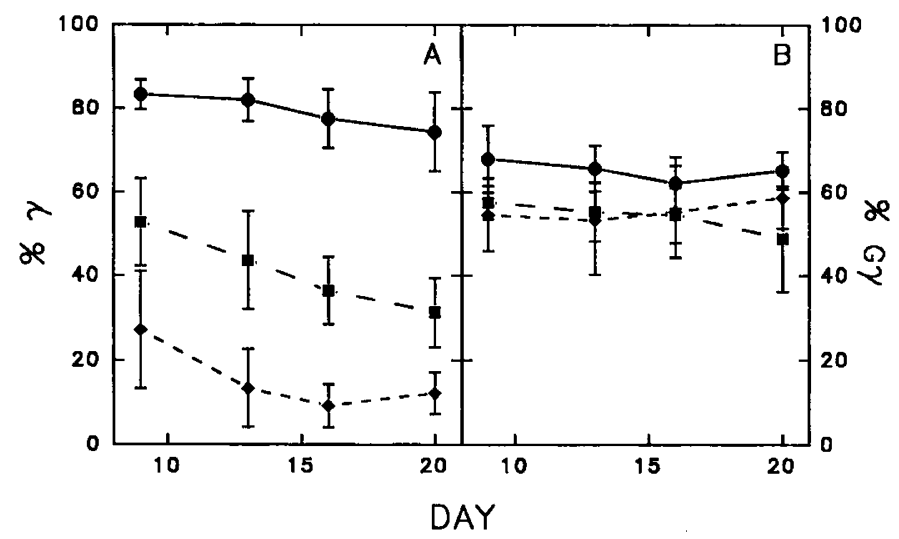

Fig. 8. Time courses of globin synthesis by blood BFU-E-derived colonies from 11 fetuses $(\bullet), 10$ newborn infants $(\square)$, and 25 adults $(\bullet)$. Data shown are the mean \pm 1 SD. $A, \% \gamma=100 \times \gamma /(\gamma+\beta) ; B, \%^{\mathrm{G}} \gamma$ $\left.=100 \times{ }^{\mathrm{G}} \gamma+{ }^{\mathrm{A}} \gamma\right)$

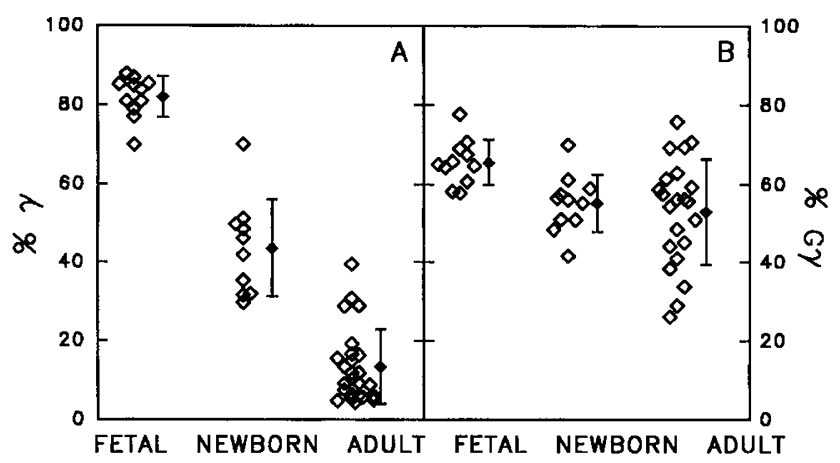

Fig. 9. Globin synthesis by $\mathrm{d} 13$ blood BFU-E-derived colonies from individual fetuses, newborn infants, and adults. Symbols as in Figure 2. $A, \% \gamma ; B, \%{ }^{\mathrm{G}} \gamma$.

accessory cells certainly changes during ontogeny, and the production of hematopoietic growth factors by those accessory cells may also change. Our previous results suggested that the BFU-E themselves were different during ontogeny [with regard to the relation between the percentage of ${ }^{\mathrm{G}} \gamma$ of ${ }^{\mathrm{A}} \gamma+{ }^{\mathrm{G}} \gamma$ and the percentage of $\gamma$ of $\gamma+\beta$ synthesis (13)], but those conclusions were also inferential. In fact, we know from blood differential counts that fetuses have fewer monocytes and granulocytes than newborns or adults $(30,31)$. We have also found that removal of adherent cells (i.e. monocytes) removes only $20 \%$ of fetal MNC compared with $50 \%$ of newborn and adult MNC (13, and unpublished data).

The results reported in this paper indicate that the phenotype of erythropoiesis changes during ontogeny. The present data do not distinguish between ontogenic changes in BFU-E and in their milieu. The next phase will require removal of accessory cells, purification of erythroid progenitors, and addition of specific defined hematopoietic growth factors to define more specifically the components responsible for the ontogenic differences. Definition of those components may permit identification of manipulations that might enhance erythropoiesis in anemia or reactivate fetal $\mathrm{Hb}$ production for hemoglobinopathies.

Acknowledgments. The authors thank Drs. James Goldberg, Charles Bowers, and Thomas Kerenyi and the nursing staff of the Department of Obstetrics and Gynecology of the Mount Sinai School of Medicine for providing fetal and newborn samples; Robert Acosta, Mandy Garber, and Drs. Gail Schewitz and Michelle Lesnick for their laboratory assistance; and Dr. Ronald Nagel for intellectually stimulating discussions of ideas and data.

\section{REFERENCES}

1. Peschle C, Migliaccio G, Lazzaro D, Petti S, Mancini G, Care A, Russo G, Mastroberardino G, Migliaccio AR, Testa U 1985 Hemopoietic development in human embryos. Blood Cells 10:427-441

2. Migliaccio G, Migliaccio AR, Petti S, Mavilio F, Russo G, Lazzaro D, Testa U, Marinucci M, Peschle C 1986 Human embryonic hemopoiesis. Kinetics of progenitors and precursors underlying the yolk sac $\rightarrow$ liver transition. J Clin Invest 78:51-60

3. Stamatoyannopoulos G, Rosenblum BB, Papayannopoulou Th, Brice M, Nakamoto B, Shepard TH $1979 \mathrm{HbF}$ and HbA production in erythroid cultures from human fetuses and neonates. Blood 54:440-450

4. Rowley PT, Ohlsson-Wilhem BM, Farley BA 1978 Erythroid colony formation from human fetal liver. Proc Natl Acad Sci USA 75:984-988

5. Beuzard Y, Vainchenker W, Testa U, Dubart A, Monplaisir N, Breton-Gorius J, Rosa J, Bouguet J, Cacheleux J, Rouyer-Fessard P 1979 Fetal to adult hemoglobin switch in cultures of early erythroid precursors from human fetuses and neonates. Am J Hematol 7:207-218

6. Hassan MW, Lutton JD, Levere RD, Rieder RF, Cederqvist LL 1979 In vitro culture of erythroid colonies from human fetal liver and umbilical cord blood. Br J Haematol 41:477-484

7. Hann IM, Bodger MP, Hoffbrand AV 1983 Development of pluripotent hematopoietic progenitor cells in the human fetus. Blood 62:118-123

8. Darbre PD, Lauckner SM, Adamson JW, Wood JG, Weatherall DJ 1981 Haemoglobin synthesis in human erythroid bursts during ontogeny: reproducibility and sensitivity to culture conditions. Br J Haematol 48:237-250

9. Linch DC, Knott LJ, Rodeck CH, Huehns ER 1982 Studies of circulating hemopoietic progenitor cells in human fetal blood. Blood 59:976-979

10. Rhondeau SM, Christensen RD, Ross MP, Rothstein G, Simmons MA 1988 Responsiveness to recombinant human erythropoietin of marrow erythroid progenitors from infants with the "anemia of prematurity." J Pediatr 112:935-940

11. Tepperman AD, Curtis JE, McCulloch EA 1974 Erythropoietic colonies in cultures of human marrow. Blood 44:659-666

12. Clarke BJ, Housman D 1977 Characterization of an erythroid precursor cell of high proliferative capacity in normal human peripheral blood. Proc Nat Acad Sci USA 74:1105-1109

13. Weinberg RS, Goldberg JD, Schofield JM, Lenes AL, Styczynski R, Alter BP 1983 Switch from fetal to adult hemoglobin is associated with a change in progenitor cell population. J Clin Invest 71:785-794

14. Alter BP, Weinberg RS, Goldberg JD, Jackson BT, Piasecki GJ, Lipton JM, Nathan DG 1983 Evidence for a clonal model for hemoglobin switching. In: Stamatoyannopoulos G, Nienhuis A (eds) Globin Gene Expression and Hematopoietic Differentiation. Alan R Liss, New York, pp 431-442

15. Weinberg RS, Antonarakis SE, Kazazian Jr HH, Dover GJ, Orkin SH, Lenes AL, Schofield JM, Alter BP 1984 Fetal hemoglobin synthesis in erythroid cultures in hereditary persistence of fetal hemoglobin and $\beta^{\circ}$-thalassemia. Blood 63:1278-1284

16. Weinberg RS, Worsley A, Gilbert HS, Cuttner J, Berk PD, Alter BP 1989 Comparison of erythroid progenitor cell growth in vitro in polycythemia vera and chronic myelogenous leukemia: only polycythemia vera has endogenous colonies. Leuk Res 13:331-338

17. Tchernia G, Mielot F, Coulombel L, Mohandas N 1981 Characterization of circulating erythroid progenitor cells in human newborn blood. J Lab Clin Med 97:322-331

18. Ogawa M, Grush OC, O'Dell RF, Hara H, MacEachern MD 1977 Circulating erythropoietic precursors assessed in culture: characterization in normal men and patients with hemoglobinopathies. Blood 50:1081-1092

19. Johnson GR, Begley CG, Matthews RN 1987 Transfusion-dependent $\beta$-thalassemia: in vitro characterization of peripheral blood multipotential and committed progenitor cells. Exp Hematol 15:394-405

20. Issaragrisil S, Grilli G, Nothdurft W, Fliedner TM 1984 Characterization of erythroid and granulocyte monocyte progenitors in human cord blood. Scand J Haematol 33:317-322

21. Shannon KM, Larrick JW, Fulcher SA, Burck KB, Pacely J, Davis JC, Ring DB 1986 Selective inhibition of the growth of human erythroid bursts by monoclonal antibodies against transferrin or the transferrin receptor. Blood 67:1631-1638

22. Shannon KM, Naylor GS, Torkildson JC, Clemons GK, Schaffner V, Goldman SL, Lewis K, Bryant P, Phibbs R 1987 Circulating erythroid progenitors in the anemia of prematurity. N Engl J Med 317:728-733

23. Kannourakis G, Johnson GR 1988 Fractionation of subsets of BFU-E from normal human bone marrow: responsiveness to erythropoietin, human placental-conditioned medium, or granulocyte-macrophage colony-stimulating factor. Blood 71:758-765

24. Kidoguchi K, Ogawa M, Karam JD, Martin AG 1978 Augmentation of fetal hemoglobin $(\mathrm{HbF})$ synthesis in culture by human erythropoietic precursors in the marrow and peripheral blood: studies in sickle cell anemia and nonhemoglobinopathic adults. Blood 52:1115-1124

25. Papayannopoulou Th, Nakamoto B, Buckley J, Kurachi S, Nute PE, Stamatoyannopoulos G 1978 Erythroid progenitors circulating in the blood of adult individuals produce fetal hemoglobin in culture. Science 199:13491350

26. Meytes D, Ma A, Powell WB, Ortega JA, Shore NA, Dukes PP 1980 Constancy of erythroid burst forming unit $\left(\mathrm{BFU}_{\mathrm{E}}\right.$ ) levels in the blood of hematologically normal individuals. Exp Hematol 8:641-644

27. Chui DHK, Wong SC, Enkin MW, Patterson M, Ives RA 1980 Proportion of 
fetal hemoglobin synthesis decreases during erythroid cell maturation. Proc Natl Acad Sci USA 77:2757-2761

28. Papayannopoulou Th, Kalmantis T, Stamatoyannopoulos G 1979 Cellular regulation of hemoglobin switching: evidence for inverse relationship between fetal hemoglobin synthesis and degree of maturity of human erythroid cells. Proc Natl Acad Sci USA 76:6420-6424

29. Papayannopoulou Th, Kurachi S, Brice M, Nakamoto B, Stamatoyannopoulos G 1981 Asynchronous synthesis of $\mathrm{HbF}$ and $\mathrm{HBA}$ during erythroblast maturation. Il. Studies of ${ }^{\mathrm{G}} \gamma,{ }^{\mathrm{A}} \gamma$, and $\beta$ chain synthesis in individual erythroid clones from neonatal and adult BFU-E cultures. Blood 57:531-536 30. Millar DS, Davis LR, Rodeck CH, Nicolaides KH, Mibashan RS 1985 Normal blood cell values in the early mid-trimester fetus. Prenatal Diagnosis 5:367373

31. Forestier F, Daffos F, Galacteros F, Bardakjian J, Rainaut M, Beuzard Y 1986 Hematological values of 163 normal fetuses between 18 and 30 weeks of gestation. Pediatr Res 20:342-346

\section{Announcement \\ Fifth International Pediatric Surgical Research Workshop}

The Fifth International Pediatric Surgical Research Workshop will be held on May 29, 1992 in Ferrara, Italy. For further information, contact: Dott. Andrea Franchella, Chirurgia Pediatrica, Arcispedale S. Anna, 44100 Ferrara, Italy, Telephone: (39) 532 295580, FAX: (39) 532 209819. 